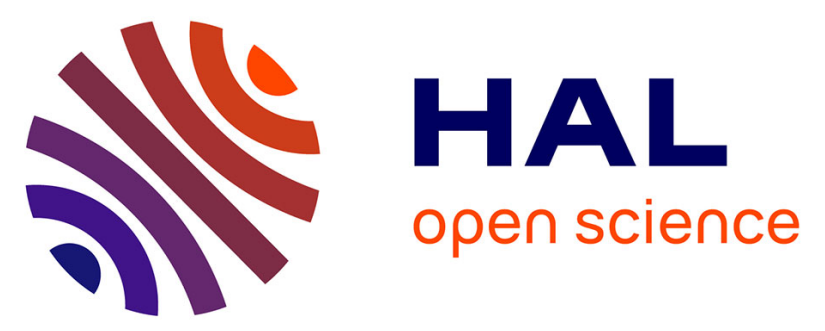

\title{
The Influence of Social Media on Engendering Strategic Organisational Practices - The Case of Two Tanzanian Telecommunications Companies
}

\author{
Shirumisha Kwayu, Banita Lal, Mumin Abubakre
}

\section{To cite this version:}

Shirumisha Kwayu, Banita Lal, Mumin Abubakre. The Influence of Social Media on Engendering Strategic Organisational Practices - The Case of Two Tanzanian Telecommunications Companies. International Working Conference on Transfer and Diffusion of IT (TDIT), Jun 2018, Portsmouth, United Kingdom. pp.47-59, 10.1007/978-3-030-04315-5_4 . hal-02068943

HAL Id: hal-02068943

https://hal.inria.fr/hal-02068943

Submitted on 15 Mar 2019

HAL is a multi-disciplinary open access archive for the deposit and dissemination of scientific research documents, whether they are published or not. The documents may come from teaching and research institutions in France or abroad, or from public or private research centers.
L'archive ouverte pluridisciplinaire HAL, est destinée au dépôt et à la diffusion de documents scientifiques de niveau recherche, publiés ou non, émanant des établissements d'enseignement et de recherche français ou étrangers, des laboratoires publics ou privés. 


\title{
The Influence of Social Media on Engendering Strategic Organisational Practices - The Case of Two Tanzanian Telecommunications Companies
}

\author{
Shirumisha Kwayu, Banita Lal and Mumin Abubakre \\ PhD Student, Nottingham Trent University, Nottingham, UK \\ Shirumisha.kwayu2014@my.ntu.ac.uk \\ Senior lecturers, Nottingham Trent University, Nottingham, UK \\ \{Banita.lal, Mumin.Abubakre\}@ntu.ac.uk
}

\begin{abstract}
.
The plethora of social media platforms such as Facebook, twitter, Instagram and WhatsApp has enhanced the information systems within organisations while at the same time being a conundrum to executives, who need to develop strategy around this technology. This paper explores the influence of different social media applications on engendering strategic organisational practices using a practice perspective. Through the practice lens and with the guidance of the interpretivist philosophy, this paper collects empirical evidence from two telecom organisations in Tanzania. The findings show that different types of social media applications play different roles in engendering different strategizing methods, such as formal and informal. depending on the role the application plays. In practice, this will help organisational executives in the selection of social media applications, which is a crucial stage in the development of social media strategy.
\end{abstract}

Keywords: Social Media, Practice Perspective, WhatsApp, Strategizing.

\section{Introduction}

The plethora of social media platforms such Facebook, twitter, Instagram, YouTube and WhatsApp create an ecosystem of social media (Hanna et al, 2011) which enhances Information Systems (IS) within organisations through revitalising fundamental processes such as sharing information and receiving feedback from customers and staff (Kwayu et al, 2017). Consequently, this enables organisations to leverage social relationships such as staff relationships as well as customer relationships, which can lead to various benefits such as extending the spheres of marketing (Berthon et al 2012). On the other hand, the existence of social media platforms within organisations contributes to democratizing organisational communication, thereby reducing organisational control of information while increasing the power of consumers. As a result, most executives 
are unable and reluctant to develop strategies and resources for engaging effectively with social media (Kietzmann et al, 2011). The reason being that social media platforms can take various forms such as content communities, social networking sites or blogs (Kietzamann et al, 2011), which illuminates different ways in which social media intertwines with communication practices such as broadcasting, chatting and sharing that occur outside and within the organisation (Treem and Leonardi, 2012). Thus, collectively, the co-existence of varying forms of social media platforms in organisations complicates the development of social media strategy within an organisation because of the 'one size fits all' approach (Jarzabkowski, 2005). The 'one size fits all' approach is a single strategy for different forms of social media application that exist in an organisation.

Although the use of social media within organisations has advanced in many spheres, the practical application of social media has outpaced the existing empirical studies which examine their use and how social media may change several organisational processes (Leonardi and Vast, 2016). This suggests that organisations are using social media, yet there is a lack of detailed empirical examination of how social media are used and the impact upon organisational practices and strategy. Considering this shortcoming, there is an apparent need for further research to understand these technologies and their effect on different processes, which will help organisations with their strategizing.

Considering the practice of social media in organisations is far beyond the scholarship as aforementioned, this research adopts a practice perspective, which focuses on emergent practices that are enacted from recursive interaction between people and technology (Orlikowski, 2000). In addition, the practice perspective encompasses the complexity entwined between people and technology while embedded within a context, making it a suitable approach for studying dynamic technology such as social media without undermining the role of people or technology in contributing to change and stability.

In light of the above, the main question for this research is: do different social media platforms create different strategic organisational practices? An interpretivist approach with empirical data from two Tanzanian telecommunications organisations will be used to answer this question. The data is collected through semi-structured interviews with staff and management within the organisations. Thus, this research aims to explore and understand the role of different social media applications in the organisations from the context of the Tanzanian telecommunications industry. Subsequently, it will help us to understand how the type of social media application associates with, and impacts upon, important organisational processes such as customer service and staff welfare (Kietzmann et al, 2011). In theory, this will enhance existing understanding and literature on social media classification, by helping to differentiate and understand different forms and their implications on organisational processes and practices. In practice, this research will help managers to set policies and procedures that will maximise the impact of social media applications on processes within the organisation. 
The remainder of this paper is organised as follows: we first discuss the literature review of social media applications and then the practice perspective. This is followed by the methodology, findings, discussion and, finally, the conclusion.

\section{Social media applications}

Social media use is increasingly becoming mainstream within organisations (Pillet and Carillo 2016) affecting firms in a number of ways including reputation, socialisation, knowledge sharing, and power dynamics (Treem and Leonardi, 2012). For example, the ranking mechanism on social media applications such as TripAdvisor have shifted power to the consumer, subsequently influencing the reputations of hotels. Thus, considering the effect of social media on organisations and the complexity created by the various forms of social media, several studies have explained how organisations can understand the various forms of social media platforms so that they can develop their respective social media strategy. Kaplan and Haenlein (2010) classified social media into six categories using theories from media and social processes, which are two key elements of social media. They used the 'social presence theory' which suggests that media differ in the degree of social presence allowed to emerge between two communication partners (Short et al 1976). In addition, they also used the 'media richness theory', which assumes that the goal of any communication is the resolution of ambiguity and reduction of uncertainty (Daft and Lengel, 1986). However, with respect to social process, they used self-representation and self-disclosure, whereby self-representation argues that in any social interaction, people have desires to control the impressions that other people have of them, while self-disclosure is the critical step in the development of relationships (Kaplan and Haenlein, 2010). Combining these two elements, the media richness theory and social presence theory, Kaplan and Haenlein (2010) established the types of social media that are collaborative projects (i.e. Wikipedia), blogs, content communities (i.e. YouTube), social networking sites (i.e. Facebook), virtual game worlds (i.e. World of Warcraft) and virtual social worlds (i.e. Second Life). The table below illustrates further:

Table 1. Classification of social media by social presence/media richness and self-representation/self-disclosure

\begin{tabular}{|c|c|c|c|c|}
\hline & \multicolumn{3}{|c|}{ Social presence / Media richness } \\
\hline & & low & Medium & High \\
\hline \multirow{2}{*}{$\begin{array}{c}\text { Self- } \\
\text { presentation / } \\
\text { Self-disclo- } \\
\text { sure }\end{array}$} & High & $B \log s$ & $\begin{array}{c}\text { Social Net- } \\
\text { working Sites } \\
\text { (e.g. Facebook) }\end{array}$ & $\begin{array}{l}\text { Virtual So- } \\
\text { cial Worlds } \\
\text { (e.g. Second } \\
\text { Life) }\end{array}$ \\
\hline & Low & $\begin{array}{l}\text { Collaborative } \\
\text { Projects (e.g. } \\
\text { Wikipedia) }\end{array}$ & $\begin{array}{c}\text { Content } \\
\text { Communities } \\
\text { (e.g. YouTube) }\end{array}$ & $\begin{array}{l}\text { Virtual } \\
\text { Game Worlds } \\
\text { (e.g. World of } \\
\text { Warcraft) }\end{array}$ \\
\hline
\end{tabular}


Source: Kaplan and Haenlein (2010)

Apart from Kaplan and Haenlein's (2010) classification of social media, Kietzmann et al (2011) presented a framework for analysing social media according to functions. Kietzmann et al's (2011) seven functional blocks are significant in explaining the user experience on the specific features of social media and its implication for organisations. The functional blocks are neither exclusive nor do they all need to be on each social media platform. For instance, twitter facilitates conversation and sharing through tweeting and retweeting, while Facebook embodies the identity function through setting up of profiles. Below is the list of the functions with their meaning and implications for organisations:

Table 2. The functional block table of social media

\begin{tabular}{|c|c|c|}
\hline $\begin{array}{l}\text { Functional } \\
\text { Block }\end{array}$ & Meaning & Impact \\
\hline Presence & $\begin{array}{l}\text { The extent to which users } \\
\text { know if other are available }\end{array}$ & $\begin{array}{l}\text { Creating and managing the } \\
\text { reality, intimacy and immedi- } \\
\text { acy of the context }\end{array}$ \\
\hline Relationship & $\begin{array}{l}\text { The extent to which users } \\
\text { relate to each other }\end{array}$ & $\begin{array}{l}\text { Managing the structural } \\
\text { and flow properties in a net- } \\
\text { work of relationships }\end{array}$ \\
\hline Reputation & $\begin{array}{l}\text { The extent to which users } \\
\text { know the social standing of } \\
\text { others and content }\end{array}$ & $\begin{array}{l}\text { Monitoring the strength, } \\
\text { passion, sentiment and reach } \\
\text { of users and brands }\end{array}$ \\
\hline Groups & $\begin{array}{l}\text { The extent to which users } \\
\text { are ordered or form communi- } \\
\text { ties }\end{array}$ & $\begin{array}{l}\text { Membership rules and pro- } \\
\text { tocols }\end{array}$ \\
\hline Conversations & $\begin{array}{l}\text { The extent to which users } \\
\text { communicate with each other }\end{array}$ & $\begin{array}{l}\text { Conversation velocity and } \\
\text { the risks of starting and join- } \\
\text { ing }\end{array}$ \\
\hline Sharing & $\begin{array}{l}\text { The extent to which users' } \\
\text { exchange, distribute and re- } \\
\text { ceive content }\end{array}$ & $\begin{array}{l}\text { Content management sys- } \\
\text { tem and social graph }\end{array}$ \\
\hline Identity & $\begin{array}{l}\text { The extent to which users } \\
\text { are ordered or form communi- } \\
\text { ties }\end{array}$ & $\begin{array}{l}\text { Data privacy controls and } \\
\text { tools for user self-promotion }\end{array}$ \\
\hline
\end{tabular}

Source: Kietzmann et al (2011)

Furthermore, considering the myriad of social media platforms, Piskorski (2014) explains why some social media platforms are more successful than others. He argues that social media applications become successful by providing a single social solution and, once it provides two or more social solutions, it becomes less effective. Given this phenomenon, social media platforms refrain from copying social solutions from other social media platforms to avoid ineffectiveness; hence, this is the reason why different platforms with non-overlapping social solutions can co-exist in an organisation. A social solution is a solution to alleviate social failures and social failures highlight unmet 
social needs that can occur due to social or economic reasons (Piskorski, 2014). For example, LinkedIn offers a social solution of connecting a job seeker with employers whereas Facebook offers a friend solution by connecting friends.

Despite the above explanations of understanding social media applications, any form of classification of social media platforms is still complex due to the multifariousness of social media platforms as well as the continuous updates and developments of social media technology. Consequently, the changing nature of social media applications complicates the classification of social media applications: resultantly, this provides challenges for executives in identifying ways of managing social media in organisations (Culnan et al, 2010). Although the classification process is complex, the above studies have made a considerable effort to classify them through various theories which, in general, have highlighted the importance of examining specific features of social media applications and their implications for organisations. For instance, Locke et al (2018) suggest that digital activism (i.e. the \#MeToo campaign) on twitter is both powerful and unique in its reach because of the way that twitter space is configured. In addition, the above studies have indicated the different attributes of social media applications and their possible impact as well as the existence of multiple platforms within an organisation. Our study intends to go further and add to this existing body of knowledge by deploying the practice theory and using empirical evidence to identify the facets of social media platforms and the specific role they play in organisations.

\section{$3 \quad$ Practice Theory}

Scott and Orlikowski (2014) suggest the practice theory as a suitable lens for understanding dynamic technology such as social media since it does not assume stability, predictability or completeness of technology. The practice theory focuses on how people interact with technology in their ongoing activities while enacting structures that influence the emergent and situated use of that technology (Orlikowski 2000). In addition, Orlikowski (2007) conceptualises practice as material since activities are dependent upon material arrangement in which the activities are taking place. For example, information searching through Google depends on Google's page ranking algorithm. Furthermore, the practice theory emphasises the causal relationship that exists between technology, organisational structure and processes, which is located on the interaction of people and technology (Avgerou, 2017). Thus, the practice perspective positions us to understand the role of a technology (in this case social media) within the organisation, since it focuses on the activity; hence, enabling us to correlate the facet (materiality) of the technology and its function.

Kwayu et al (2017) suggest that the practice perspective can help to understand how social media affects strategy, processes and structure as it considers the social context that enables us to gain insight on reality that is dynamic and complex. Also, considering that the social media effect is multiple, dynamic and contemporaneous (Scott and Orlikowski, 2012), the focus on practice enables us to capture the reality in the organisation when people interact with social media. 


\section{$4 \quad$ Methodology}

This research is guided by an interpretivist philosophy that views knowledge as being socially constructed through language, shared meaning and consciousness (Richey et al 2018). This philosophy is in line with the nature of this research since practices can be regarded as accomplished social activities through the interpretation of practitioners (Orlikowski and Baroudi, 1991). In addition, it is qualitative research, where data is collected through semi-structured interviews with staff from two telecom organisations in Tanzania. Pseudo names used for the two organisations are are Kurwa and Dotto: both organisations are large with networks across the country and both have adopted social media. The choice of Tanzania, an emerging market, offers a novel context of understanding the impact of Information Technology (IT) on organisations that operate from a different context to the developed world, especially when considering the digital divide that exists between the developed and developing country (Kwayu et al, 2017).

Twenty interviews were conducted with managers and staff from different departments within the respective telecom organisations. The language used was a mix of Swahili and English, depending on the comfort level of the respondent with both languages. The first author, who conducted the interviews, is Tanzanian and fluent in both languages. The interviews were recorded and transcribed, translated and analysed. The analysis process followed an inductive approach, which extracted themes and issues to concentrate upon (Glaser and Strauss 1967). A narrative structuring method was used for analysis: the narrative style is a powerful method of capturing different aspects of our lives without undermining the role of social or material aspects in contributing to stability and change (Golsorkhi et al, 2015). Following the narrative style, our analysis consisted of four main stages that are: summarizing, clustering, displaying and narrating (Pan and Tan 2011). The summarising stage was through unitizing, which is a coding operation where information is extracted from the text. Hence, this produced units of analysis, which are interview segments that range from phrase/ sentence to paragraph. Then, the clustering stage where the units were categorised which gave rise to themes such as: WhatsApp group communication, social media marketing, feedback and social media management. Though codes and themes were produced, Saunders et al (2009) suggest that the narrative style should focus on the originally told form rather than fragmentation, which is done through coding and themes. In addition, Kvale (1996) suggest that narrative structuring should ensure that data is organised temporally while regarding social and organisational context, thus, focusing the story and plots.

\section{$5 \quad$ Findings}

In both telecom organisations, social media practice was similar; this section will provide a narrative of social media practice within the two telecom organisations. Different social media applications such as Facebook, twitter, Instagram, YouTube and WhatsApp are common in both organisations. Other examples of social media use within these companies include blogs and social forums such as Jamiiforums, but on a very minimal scale. In general, there are two distinctive ways in which these social 
media applications are used by the two telecom organisations. These are for external communication, which is associated with marketing, and for internal communication. External communication is communication between the organisation and the customers or the general public. Facebook, Instagram, YouTube, twitter and blogs are used for external communication. The WhatsApp application is used for internal communication. Internal communication is communication taking place inside the organisation between employees within the organisation.

The Human Resources Manager at Kurwa explains the social media practice as follows.

We have not encouraged people to use social media, nevertheless what we have done we said it should be used for marketing. That is what we have accomplished to this point. Although indirectly we use WhatsApp when we have something to share, work. We share in WhatsApp groups with different people for instance finance or other departments. - Human Resources Manager, Kurwa

As can be deduced from the quote above, social media is intended to be used for marketing specifically. However, informally, WhatsApp is also used internally for work purposes although there is no apparent set procedures or requirements in place to use it for this purpose. The internal and external use shows how a social media application can be identified by the role it plays in an organisation. For example, Facebook, twitter, Instagram can form a category of applications used for external use while WhatsApp application can be categorised as application used for internal use.

Social media applications that are used for external communication help the organisations with functions such as marketing (as abovementioned), public relations and provides a means of getting feedback from customers. These social media platforms used for external communications are carefully selected by the custodians of the organisation communication. Kurwa's Public Relations Manager and Product Development Manager expand on this as follows:

There are many social media but we have selected a few. We chose those, which we can work with them in an easy way. We look at those, which we can do filtering, we can follow up, we can change people ideas, we can get people opinion, and we can ban bad information. -Public Relation Manager, Kurwa

Customers provide feedback through different social media platforms, the groups and social media pages, which our $P R$ manage. We are on Facebook, twitter YouTube, Instagram and Jamii forums. We on different platforms and we use them to gather feedbacks, complains, and desires of customers. 


\begin{abstract}
Sometimes we answer all their questions. Therefore, we communicate with customers through these platforms. Hence, we use the platform to help the customers. - Product Development Manager, Kurwa
\end{abstract}

The WhatsApp application, which is associated with internal communication, involves staff communicating with other staff either on a one-to-one basis or through groups. The group communication has significantly enhanced collaboration and teamwork within the telecom organisations. In addition, WhatsApp works in parallel with email communication. In some instances, WhatsApp communication substitutes email while at other times WhatsApp communication complements email communication. Although WhatsApp communication is informal and there is no formalised processes in place regarding how and when it should be used, it is a more popular means of communication across departments and organisational levels when compared to formal means such as email communication. This is the case because WhatsApp is faster and easier to use and access than email. Hence, WhatsApp communication facilitates quick solutions which consequently speeds up processes and enhances staff collaboration. Below are some of the explanations that narrate the use of WhatsApp within the telecom organisations in Tanzania:

Those are initiative of individual departments. For example, we from regional branches every unit has its own WhatsApp group. Where they can share work related issues, jokes and do whatever. - Regional Manager, Kurwa

Our office uses WhatsApp. I have a WhatsApp group of eight people we update each other. Not everything you can share through email. Not all the people are using the email. For instance, there are eight customer services but the computers are two. This means some people do not have email system but they are using WhatsApp because it is modern, easy to communicate anything in the office. This is just an example of my office, but in the zone, there are many groups. There is a social group and work group. When I look at my phone I have not less than eight groups and they are all related to work. It simplifies because when you need information in time the phone is nearby. Someone is in Dar es Salaam [headquarters] and is requesting how many agents do you have in your branch. When you send it on WhatsApp group, it becomes easy because everyone shares that information in time. Branch Manager, Dotto

Confidential issues go through email. That is the relation. Email is the most formal communication and WhatsApp is 


\section{more for business updates, direction, asking quidance or way forward. - Zonal Manager, Dotto}

The distinction between the use of WhatsApp and other social media applications (Facebook, twitter and Instagram) within the telecom organisations is significant. Primarily, the WhatsApp communication is an individual initiative and the organisation has very little control over this form of communication. Thus, it can be rationalised that WhatsApp communication is a practice that emerges from the employees. In addition, although the management has no formal means like policy or procedures to use emerging social media practices like WhatsApp communication, it appears that the organisation is using an interactive way to encourage the positive use of social media, for instance the use of WhatsApp for assisting work processes as indicated above by the Zonal manager of Dotto.

Distinctively, Facebook, twitter and Instagram, which are used for external communication, have a formal recognition within the organisation. The two telecom organisations have official accounts on these platforms and management of these accounts is centralised from the headquarters. The centralisation of social media is a means of controlling practice associated with these applications, consequently enacting a formal status in the following ways. First, individual branches are not allowed to open any account on social media that represents the organisation. Through this restriction, the organisation can maintain a single voice that represents the organisation in respective platforms. Second, centralisation indicates the formal organisation role in the use of social media through backing up with resources such as personnel who manage the social media accounts. The following insights provide an interpretation on the state of social media applications that are used for external communication:

I can say that we have officialised social media because we use them for business marketing. Although we need to restrict some comments. Some comments spoil everything and may affect other people's decision. That is the greatest challenge we are facing. It needs to be open but too open is also biased. - Human Resources Manager, Kurwa

We have centralised social media, we do not allow our branches to have social media. It is difficult to manage social media from different user and whatever they have needs to represent one Kurwa. - Marketing Manager, Kurwa

They collect all the feedback and they will come and say that we get this complains about you (branch). Perhaps, there is an incidence has happened in your branch, they will call me or email me and ask me if am aware of that incidence. Therefore, we might be told to change something or do this when that happens. - Double Road Manager, Dotto 
The above findings have highlighted the state of social media in two telecom organisations in Tanzania. It has shown a distinction between social media applications, with the WhatsApp application supporting internal communication while Facebook, Instagram, and twitter support external communication. The next section will discuss the findings in conjunction with the literature and the practice theory.

\section{Discussion}

This section aims to discuss the findings using a practice perspective to explore the relationship between social media applications and their function within the two organisations. The findings reveal that social media applications are used to accomplish a particular task. For instance, Facebook, Instagram and twitter are used for communication with the customer hence supporting some of the marketing functions such as maintaining customer relationships and receiving feedback. Similarly, the WhatsApp application is used as means for internal communication between staff. From Kaplan and Haenlein's (2010) classification, we observe that applications with high self-disclosure and presentation are used for external purposes such as marketing while WhatsApp, which has low self-disclosure and presentation, is used for internal communication. On the other hand, it can also be argued that the solutions offered by the application determines their role. For example, the WhatsApp groups help collaboration between staff whereas applications such as Facebook, twitter and Instagram that allow posting are used for advertising and marketing - this corresponds with Piskorski's (2014) argument that a social media application becomes popular due to the solution that it brings. Thus, in essence, the social media applications are adopted for functions in which they were designed for, i.e. twitter, Facebook and Instagram are designed with an external outlook to support mass and open communication which orients them as marketing tools. Whereas the WhatsApp application is designed for private communication giving it an internal position within organisation communication. In theory, this suggests that the use of social media is an appropriation of structure inscribed in the application (Orlikowski, 2000). In practice, this emphasises the need to understand the structure inscribed within the social media application to understand their role in an organisation. Thus, following Culnan et al's (2010) suggestion that organisations should be mindful when adopting social media, these findings suggest that mindful adoption can be done by examining the structures inscribed within the social media application.

In addition, the findings highlight how social media is extending the scope of IS within the telecom organisations. First, the WhatsApp communication that is done through personal mobile devices substitutes and complements the corporate IT infrastructure. WhatsApp has been used in parallel with the email system in the organisation, it has also enabled the incorporation of staff who had no access to organisational IT infrastructure (i.e. computers) consequently filling that gap. Besides the deficiency of computers (corporate IT infrastructure), the branch manager of Dotto suggests things like mobility design and easiness as reasons for rise of WhatsApp communication in the company. This means that even those with computers tend to substitute or complement their formal/email communication with WhatsApp. This signifies the importance 
of materiality and the contextual arrangements as reasons for WhatsApp practice in the telecom organisations. Thus, the contextual arrangement of IT infrastructure influences the performance of social media in the organisations. This finding contrasts with Braojos- Gomez et al's (2015) argument that organisational IT infrastructure is positively related to social media competence, as the findings in this study suggest that social media conducted through personal devices can be a substitute of organisational IT infrastructure.

Additionally, the findings show that social media models new practices. For example, the zonal manager from Dotto explains thee distinctive ways in which they practice their communication by describing what sort of communication goes through email and what goes through WhatsApp. Likewise, Facebook, twitter and Instagram have shaped how customer service is carried out as the organisations gather feedback, complaints and desires of the customers. These new practices, which are engendered by social media, are significant because they influence the way organisations operate and consequently the way in which value is created. The practice perspective focuses on repetitive activities (Orlikowski, 2000) because such activities influence strategic outcomes of the organisation (Jarzakowski, 2005). For example, through practice of gathering and responding to feedback, complains and desires of customer from social media the telecom organisations can attain strategic outcomes such as increasing customer satisfaction.

Furthermore, the cases of the telecom organisations show an 'application role' based strategizing method for social media. From the practice of the organisations, the social media applications which supported external communication had a formal procedural guidance (e.g. Facebook), while for internal WhatsApp communication it was a form of interactive strategizing such as encouraging positive use. Thus, different social media applications are engendering different forms of strategizing such as formal strategizing for applications that have an external role and interactive strategizing for applications with an internal role. In general, this suggests that it is rational for an organisation to develop social media strategies by focusing on the role that social media plays in an organisation, rather than having a collective social media strategy which contains complications of the 'one size fits all' approach.

Lastly, with regards to our research question - do different social media platforms create different organisational practices? - the above discussion shows how classification, for instance by Kaplan and Haenlein (2010), can relate a social media application with its role within an organisation. Similarly, Kietzmann et al's (2011) classification can help to explain why application functions such as group functionality of WhatsApp is popular within the organisation. Likewise, this can also help to explain why applications such as Facebook, twitter and Instagram - which have the functions of presence, sharing and reputation - are useful for marketing and external communication purposes. Furthermore, the discussion has shown how the contextual arrangement and classification of social media applications are important in understanding the relationship between the application and the role it plays in organisations; thus, contextual arrangement acts as a moderating factor. Therefore, it can be argued that the classification of social media applications and contextual arrangement can help to determine the role that an application plays within the organisation. This has practical implications on 
social media strategy as it can help executives with the selection of social media applications for the organisation, which is a crucial part of developing social media strategy (Culnan et al, 2010). Also, by understanding the role that each social media application is playing within an organisation, this can help the organisation to decide a form of strategizing; for instance, through a procedural or an interactive way.

\section{Conclusion}

Social media represents one of the most dynamic forms of information technology in contemporary organisations. The various forms it takes and the functions it performs is a perplexity facing organisations' executives. Efforts to understand the technology are important for helping executives to develop strategy. This research has shown how different social media applications play different roles within organisations engendering different forms strategizing such as formal (procedural) strategizing for applications which had an external role and informal (interactive) strategizing for applications that had an internal role. Thus, this signifies the importance of differentiating social media applications by classifying them to assist in identifying the types of practices that can manifest within organisations. Therefore, this is significant for strategy development as it helps in the selection of social media platforms. Culnan et al (2010) identifies mindful adoption as an initial and crucial stage in developing social media strategy. Also, this study highlights the importance of the environment in which the selected social media is going to be appropriated. Evidence presented in our research is just an indication; future research can advance this study by exploring the relationship between the different organisational practices, i.e. formal and informal, engendered by different social media types and the development of organisational strategies. Lastly, future research may explore the impact of social media applications such as WhatsApp on creating blurred boundaries between work and play, which is something highlighted in this study.

\section{Reference}

1. Avgerou, C. (2017). Theoretical Framing of ICT4D Research. In J. Choudrie, M. Islam, F. Wahid, J. Bass, \& J. Priyatma (Eds.), Information and Communication Technologies for Development. ICT4D 2017, IFIP advances in information and communication technology, vol 504. Cham: Springer.

2. Berthon, P. R., Pitt, L. F., Plangger, K., \& Shapiro, D. (2012). Marketing meets web 2.0, social media, and creative consumers: Implications for international marketing strategy. Business Horizons, 55(3), 261-271. https://doi.org/10.1016/j.bushor.2012.01.007.

3. Culnan, M., mchugh, P., \& Zubillaga, J. (2010). How large u.S. companies can use twitter and other social media to gain business value. MIS Quarterly Executive, 9(4), 243-259

4. Daft, R.L. and Lengel, R.H., 1986. Organizational information requirements, media richness and structural design. Management science, 32(5), pp.554-571.

5. Glaser, B., \& Strauss, A.(1967).Thediscoveryofgroundedtheory.1967 (pp. 1-19). London: Weidenfield \& Nicolson. 
6. Golsorkhi, D., Rouleau, L., Seidl, D., \& Vaara, E. (Eds.). (2015). Cambridge handbook of strategy as practice. Cambridge: Cambridge University Press. https://doi.org/10.1017/ CBO9781139681032

7. Hanna, R., Rohm, A. and Crittenden, V.L., 2011. We're all connected: The power of the social media ecosystem. Business horizons, 54(3), pp.265-273.

8. Kaplan, A.M. and Haenlein, M., 2010. Users of the world, unite! The challenges and opportunities of Social Media. Business horizons, 53(1), pp.59-68.

9. Kietzmann, J. H., Hermkens, K., McCarthy, I. P., \& Silvestre, B. S. (2011). Social media? Get serious! Understanding the functional building blocks of social media. Business Horizons, 54(3), 241-251. https://doi.org/10.1016/j.bushor.2011.01.005

10. Kvale, S., 1996. The 1,000-page question. Qualitative inquiry, 2(3), pp.275-284.

11. Kwayu, S., Lal, B. and Abubakre, M., 2017. Enhancing Organisational Competitiveness Via Social Media-a Strategy as Practice Perspective. Information Systems Frontiers, pp.1-18.

12. Leonardi, P., \& Vaast, E. (2016). Social media and their affordances for organizing: a review and agenda for research. Academy of Management Annals, 11(1), 150-188.

13. Locke, A., Lawthom, R. and Lyons, A., 2018. Social media platforms as complex and contradictory spaces for feminisms: Visibility, opportunity, power, resistance and activism.

14. Orlikowski, W.J.(2000).Using technology and constituting structures: A practice lens for studying Technology in Organizations. Organization Science, 11(4), 404-428. https://doi.org/10.1287/ orsc.11.4.404.14600.

15. Orlikowski, W. J. (2007). Sociomaterial practices: Exploring technology at work. Organization Studies, 28(9), 1435-1448.https://doi.org/10. 1177/0170840607081138.

16. Orlikowski, W.J., \& Baroudi, J.J . (1991).Studying information technology in organizations: Research approaches and assumptions. Information Systems Research, 2(1), 1-28. https://doi.org/10.1287/ isre.2.1.1.

17. Pan, S. L., \& Tan, B. (2011). Demystifying case research: A structured- pragmatic-situational (SPS) approach to conducting case studies. Information and Organization, 21(3), 161176. https://doi.org/10. 1016/j.infoandorg.2011.07.001.

18. Pillet, J. C., \& Carillo, K. D. A. (2016). Email-free collaboration: An exploratory study on the formation of new work habits among knowledge workers. International Journal of Information Management, 36(1), 113-125. https://doi.org/10.1016/j.ijinfomgt. 2015.11.001.

19. Piskorski, M. J. (2014). A social strategy: How we profit from social media. Princeton: Princeton University Press. https://doi.org/10. 1515/9781400850020.

20. Richey, M., Gonibeed, A., \& Ravishankar, M. N. (2018). The perils and promises of selfdisclosure on social media. Information Systems Frontiers. https://doi.org/10.1007/s10796017-9806-7.

21. Scott, S. V., \& Orlikowski, W. J. (2012). Reconfiguring relations of accountability: Materialization of social media in the travel sector. Accounting, Organizations and Society, 37(1), 26-40. https://doi. org/10.1016/j.aos.2011.11.005.

22. Scott, S., \& Orlikowski, W. (2014). Entanglements in practice: performing anonymity through social media. MIS Quarterly, 38(3), 873-893. https://doi.org/10.25300/misq/2014/38.3.11.

23. Short, J., Williams, E. and Christie, B., 1976. The social psychology of telecommunications.

24. Treem, J. W., \& Leonardi, P. M. (2012). Social media use in organizations: Exploring the affordances of visibility, editability, persistence, and association. Communication Yearbook, $36,143-189$. 